\title{
Combined Floating Offshore Wind and Solar PV
}

\author{
Mario López ${ }^{1}$, Noel Rodríguez ${ }^{1}$ and Gregorio Iglesias ${ }^{2,3, *(1)}$ \\ 1 DyMAST Research Group \& Department of Construction and Manufacturing Engineering, University of \\ Oviedo, EPM, C/Gonzalo Gutiérrez Quirós s/n, 33600 Mieres, Asturias, Spain; mario.lopez@uniovi.es (M.L.); \\ noelrodriguez5@gmail.com (N.R.) \\ 2 MaREI, Environmental Research Institute \& School of Engineering, University College Cork, College Road, \\ P43 C573 Cork, Ireland \\ 3 School of Engineering, University of Plymouth, Drake Circus, Plymouth PL4 8AA, UK \\ * Correspondence: gregorio.iglesias@ucc.ie; Tel.: +35-(321)-490-2523
}

Received: 8 July 2020; Accepted: 28 July 2020; Published: 30 July 2020

\begin{abstract}
To mitigate the effects of wind variability on power output, hybrid systems that combine offshore wind with other renewables are a promising option. In this work we explore the potential of combining offshore wind and solar power through a case study in Asturias (Spain)—a region where floating solutions are the only option for marine renewables due to the lack of shallow water areas, which renders bottom-fixed wind turbines inviable. Offshore wind and solar power resources and production are assessed based on high-resolution data and the technical specifications of commercial wind turbines and solar photovoltaic (PV) panels. Relative to a typical offshore wind farm, a combined offshore wind-solar farm is found to increase the capacity and the energy production per unit surface area by factors of ten and seven, respectively. In this manner, the utilization of the marine space is optimized. Moreover, the power output is significantly smoother. To quantify this benefit, a novel Power Smoothing (PS) index is introduced in this work. The PS index achieved by combining floating offshore wind and solar PV is found to be of up to $63 \%$. Beyond the interest of hybrid systems in the case study, the advantages of combining floating wind and solar PV are extensible to other regions where marine renewable energies are being considered.
\end{abstract}

Keywords: marine renewable energy; wind energy; solar energy; resource assessment; hybrid energy systems

\section{Introduction}

The scarcity of habitable land, growing energy consumption and environmental repercussions of fossil fuels are fostering the development of renewable energy projects in the marine environment. The oceans receive $70 \%$ of the global primary energy resource: radiation from the sun [1]. Intensive research is devoted to developing technologies in offshore wind, wave and tidal energy as the main forms of marine renewable energy [2].

Regarding wave energy, there exists a vast resource with a high energy density and good predictability, two properties of major interest for electricity generation [3]. For this reason, many wave energy conversion concepts have been proposed during the past decades. Most of the wave energy converters can be grouped into one of the following categories: oscillating systems (e.g., CECO [4]), overtopping devices (e.g., Wavecat [5]) and oscillating water columns (e.g., [6]). However, despite the large research effort and number of available concepts, no technology appears to be mature enough at this point for commercial projects [7].

Tidal energy is another well-known marine renewable energy, which can be harvested by means of either tidal barrages or tidal stream turbines. Tidal barrages are a well-proven technology but have two major downsides-the large capital expenditure required, and the environmental impact [8]. 
As for tidal stream turbines, the locations of interest, i.e., where a project can be economically viable, are limited [9].

As for wind energy, offshore farms have been in operation and connected to the grid since the 1990's, and have experienced a substantial growth in the last decade, especially in Europe [10]. These commercial farms consist of wind turbines fixed to the sea bottom in water depths below $50 \mathrm{~m}$ by means of foundations, such as monopiles, gravity structures, jackets, tripods, and tripiles ([11], Figure 1). Nonetheless, because of the limited amount of shallow waters for deploying fixed foundations, most of the future offshore wind farms will be installed in deeper water [12]. For this purpose, wind turbines with floating foundations are required, with some concepts already tested under real conditions in the recent years (e.g., WindFloat [13]).

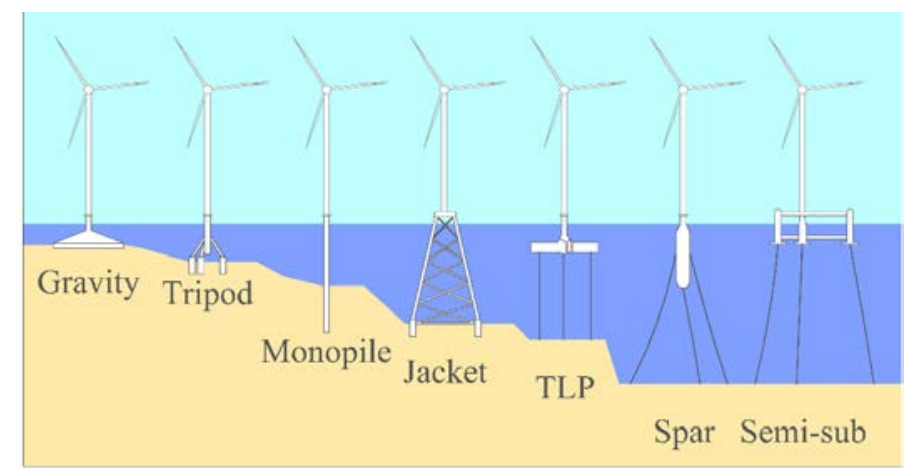

(a)

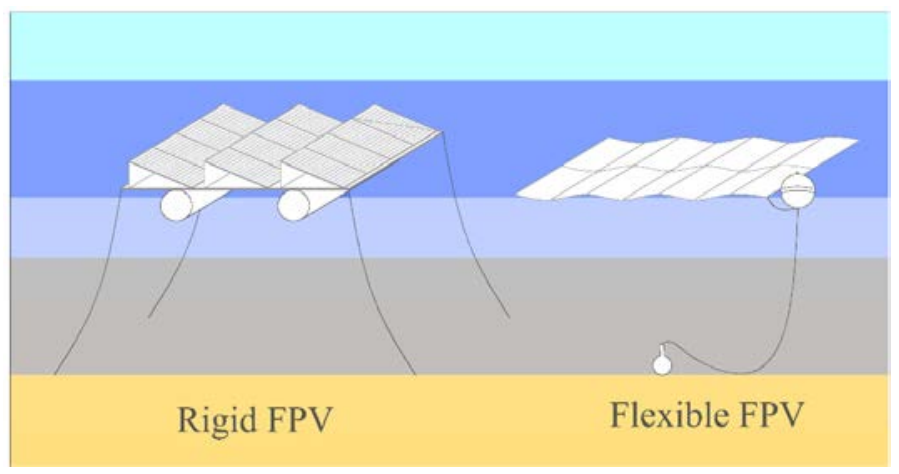

(b)

Figure 1. Different types of offshore wind turbine foundations (a) and floating photovoltaic (FPV) systems (b).

In addition to these marine renewable energy resources, there is an alternative that has been little explored in the marine environment: solar energy [14]. To harvest this resource in the oceans and seas, floating photovoltaic (FPV) systems are required (Figure 1). Although applying this technology in the marine environment is new, FPV farms have been deployed worldwide in freshwater, including lakes and reservoirs [15]. The main advantage of FPV systems against land-based ones is the water cooling on the solar cells [16]. This effect results in a higher energy conversion efficiency of the floating panels, which can generate up to 10\% more electricity [17]. Other advantages of offshore FPV systems include: the availability of abundant water for cleaning the panels, the scalability of the systems from microwatt to megawatt, and the reduction in the growth of algae by the shading effect of the panels [14].

FPV systems in the marine environment can be more economical than wind farms at latitudes between $45^{\circ}$ South and $45^{\circ}$ North [18]. On these grounds, China and the Netherlands have started to deploy FPV systems in their maritime areas [19]. Notwithstanding, much work remains to be done in assessing the offshore photovoltaic potential (only a handful of areas investigated so far, e.g., India [20] 
and the Maltese islands [21]), and in developing reliable structures to resist the accelerated rusting in saltwater and the extreme dynamics of the marine actions (mainly winds, waves and tides) [22].

On another note, the combination of marine renewable energies is a promising solution that is supported by many synergies, such as the increase in the energy production and the reduction in the operation and maintenance cost [23]. Previous studies have shed light on the synergies between wind and wave energy, including topics such as the optimal array design (e.g., [24]) and the reduction in operation and maintenance costs (e.g., [25]). Nonetheless, wind-solar farm synergies remain unexplored, and only their combined use with aquaculture has been proposed [26]. Bearing in mind this scenario, the potential of combined wind-solar farms should be evaluated. A basic arrangement would be filling with FPV panels the free-surface amidst the offshore wind turbines, which avoids interferences in the production of both renewables (Figure 2).

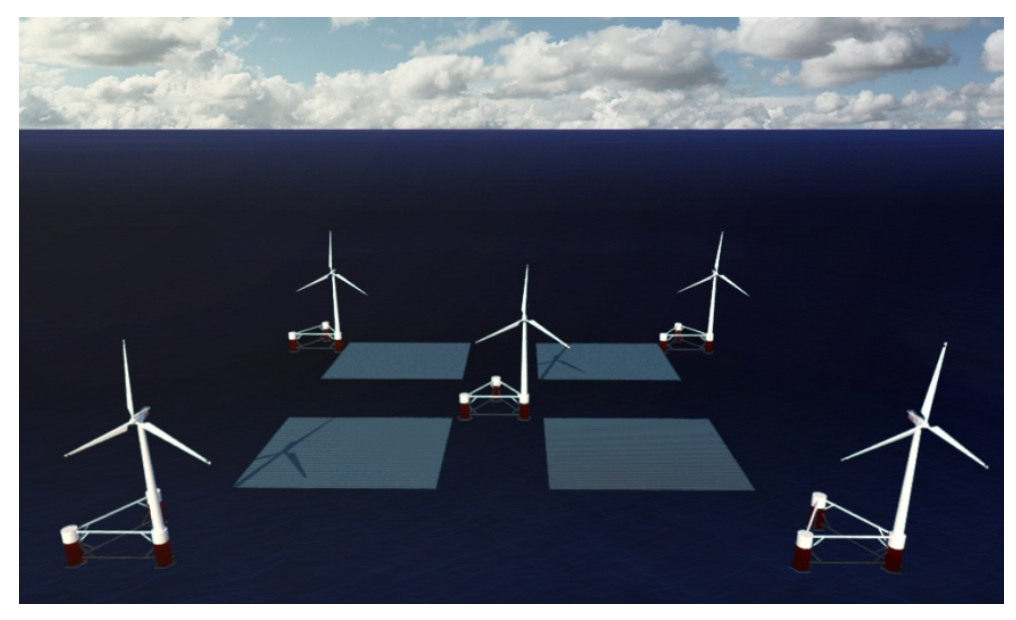

(a)

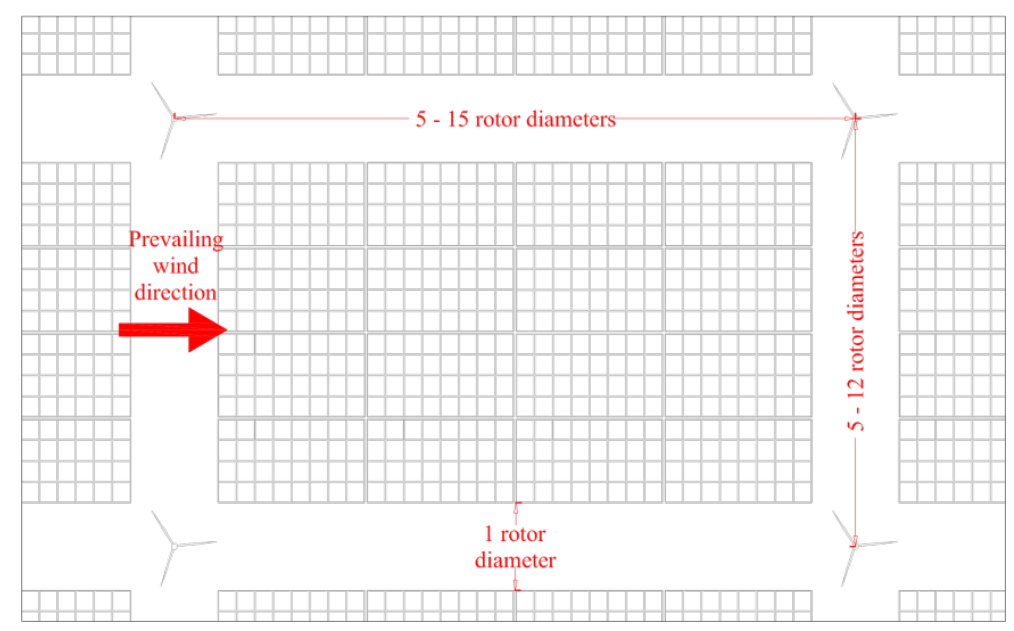

(b)

Figure 2. Combined floating wind and solar energy farm: general view (a) and schematic layout (b).

Asturias, a coastal region in Northern Spain with more than $300 \mathrm{~km}$ of coastline, is keen to develop its marine renewable energy potential. The wave energy resource in Asturias has been assessed [27]. Recently, Abanades et al. [28] proposed using wave energy converters in this region with a dual-purpose: the production of carbon-free energy and the mitigation of coastal erosion-a severe issue in the context of climate change. Regarding tidal energy, the available locations are scarce along the Asturian coastline. Some examples are the Ria of Ribadeo [29] and the Port of Aviles within the Nalon River estuary [9] (Figure 3). As for the offshore wind and solar energy resource, a detailed 
assessment is lacking. Although the narrow continental shelf compounds the deployment of fixed wind turbines, floating solutions may be used (Figure 1).

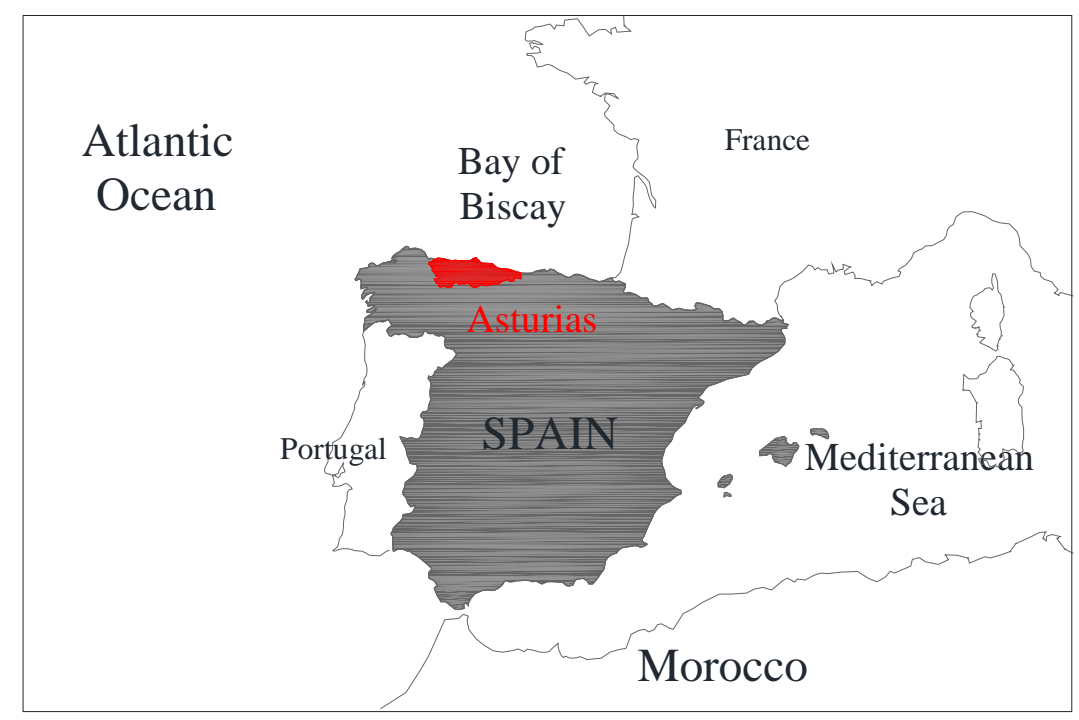

(a)

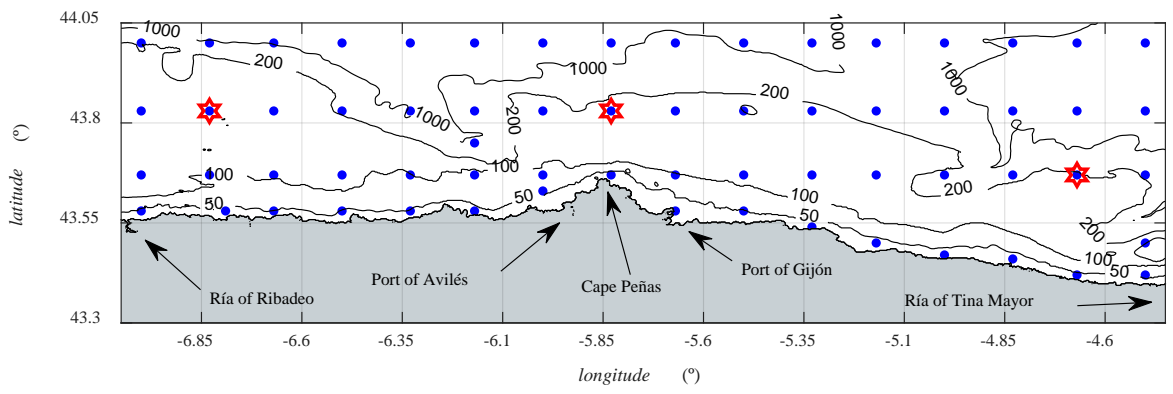

(b)

Figure 3. Location (a) and bathymetry (b) of Asturias. SIMAR data points are marked with blue dots, and the three study sites (West, Centre and East) with red stars. (Water depths in $\mathrm{m}$ ).

In this work, the potential for developing floating wind and solar energy off the coast of Asturias is assessed and the benefits of their combination are examined. For this purpose, the gross resource of each renewable across the area of study is estimated by means of the available data, mainly from observational and numerical (hindcasting) meteorological databases. Then, the expected energy production of offshore solar and wind farms-separately and combined-is estimated considering the specifications of commercial technology. In the discussion, the potentials of offshore solar and wind energy are compared, taking into account the rated power of each technology, the marine space occupation, and the variability of their power output. From the results it is clear that combined offshore wind-solar farms present a production synergy that should be considered in future marine renewable energy projects.

The remainder of this paper is structured as follows: Section 2 describes the study area and presents the data used to assess the resources, the technology specifications used to calculate the energy production, and the methodology. In Section 3, results are presented and discussed. Finally, conclusions are drawn and further research lines suggested in Section 4. 


\section{Materials and Methods}

\subsection{Study Area}

The area considered in this work is off the coast of Asturias, a region in North Spain between $43.3^{\circ}$ and $44.1^{\circ}$ North and $7.0^{\circ}$ and $4.3^{\circ}$ West (Figure 3). With only $10,603 \mathrm{~km}^{2}$ of surface area, Asturias has $334 \mathrm{~km}$ of coastline, delimited by two estuaries: the Ria of Ribadeo to the west and the Ria of Tina Mayor to the east.

The climate of Asturias is of the oceanic type, with mild temperatures both in winter and summer, and the rainfall is abundant and well distributed throughout the year. The atmospheric circulation is governed by two centres of action, the Azores High and the Iceland Low, and more specifically by the North Atlantic Oscillation (NAO), i.e., the oscillation in the difference of atmospheric pressure between them. Because of this phenomenon, the winds are strongest in winter and lighter and less regular in summer. In summer, the poleward movement of the Azores High to about $35^{\circ}$ North results in prevailing North East winds, which are cold and dry, bringing cool, clear, and rainless weather. The situation is different in winter, when the Azores High retreats to the south and allows a much more southerly trajectory of the Atlantic storms.

Wind energy areas can be grouped into classes from 1 to 7 , with each class representing a range of mean wind power density or equivalent mean wind speed [30]. The study area falls in a transition zone between the energy-rich North Atlantic (with a wind power class up to 7) and the Bay of Biscay (with a wind power class below 4) [31]. On this basis, the study area may be considered a prospective development area for offshore wind energy. Bearing in mind the latitude of the study area (below $45^{\circ}$ ), FPV energy can be even more competitive than offshore wind energy according to [18]. It has been observed that more than $60 \%$ of the Asturian surface presents values lower than $3.4 \mathrm{kWh} /\left(\mathrm{m}^{2}\right.$.day) [32]. The sites with the highest values were reported to be in the coastal area around Cape Peñas, in accordance with studies of the neighbouring region of Galicia, which also found the highest irradiance to occur in coastal areas [33].

Regarding infrastructures and facilities for the installation, operation, maintenance and decommissioning of future offshore renewable energy farms, there are two major ports in Asturias: Gijón and Avilés, on both sides of Cape Peñas (Figure 3). Both present excellent maritime and terrestrial communications, which make them a hub for international trade, mainly with the Northern Europe (the ports are about $40 \mathrm{~h}$ from the North Sea) and the Americas. Moreover, both ports have infrastructures to manufacture, assemble and operate offshore renewable energy installations.

\subsection{Spatial Data}

To assess the offshore wind and solar energy resource in Asturias, two different sources of data were used. The datasets and parameters are presented in the subsequent sections.

\subsubsection{SIMAR Dataset}

SIMAR is an hourly dataset that covers the period from 1958 to the present by concatenating two subsets: SIMAR-44 and WANA. The SIMAR-44 subset covers the period 1958-1999 and is based on the joint numerical modelling of atmosphere, sea level and waves. Wind data are obtained by means of the regional model RCA3.5 (Rossby Center regional Atmospheric model) [34], which is fed with data from the re-analysis of meteorological observations produced by the European Centre for Medium-Range Weather Forecasts (ECMWF) in collaboration with many other institutions [35]. As for the WANA subset, it spans the period from 2000 to the present and obtains the wind fields with the High Resolution Limited Area Model (HIRLAM, [36]).

In this work, data from the 64 SIMAR data points shown in Figure 2 were considered. In particular, the time series of the mean wind speed $\left(U_{10}\right)$ and mean wind direction $(\theta)$ at $10 \mathrm{~m}$ above the sea level were used. For a more detailed analysis, the data corresponding to three sites were used to characterize the West, Centre and East offshore regions of Asturias. These study sites correspond to the SIMAR data 
points nos. 3064044, 3088044, and 3116040, hereinafter referred to as points W, C and E, respectively, for the sake of simplicity (Figure 3).

\subsubsection{POWER Dataset}

To assess the offshore solar energy resource, solar radiation and air temperature data are required [37]. For this purpose, meteorological datasets from the Prediction of the Worldwide Energy Resources project (POWER) were collected [38]. POWER facilitates access to the satellite and modelling analyses of the National Aeronautics and Space Administration (NASA), which have been proved to be reliable and useful to the renewable energy sector and, especially, the solar energy industry [39]. The data in POWER are derived from the MERRA-2 assimilation model products [40] and the GEOS 5 near-real time products [41]. The MERRA-2 data spans the period from 1981 to within several months of real time. As for GEOS-5 dataset, it covers from the end of the MERRA-2 data stream to present.

Particularly, two daily time series were collected from POWER for this work: the all sky irradiance on a horizontal surface per day, $R_{h o r}$, with units of $\mathrm{W} / \mathrm{m}^{2}$, and the average air temperature at $2 \mathrm{~m}, T_{a}$, with units of ${ }^{\circ} \mathrm{C}$. These time series were retrieved for the 64 data points in Figure 3.

\subsection{Conversion Technology Overview}

\subsubsection{Offshore Wind Energy}

In the marine environment, wind turbines require fixed or floating foundations depending on the operational water depth. Fixed foundations have been in use for over two decades, and include, in order of ascending water depth: gravity base, tripod, monopile and jacket-type (Figure 1). Floating foundations have started to be used more recently, in experimental windfarms such as Hywind and Windfloat, and target deeper waters, between 50 to $200 \mathrm{~m}$ [12] — the reason being their lower costs for construction, installation and decommissioning in this range of water depths [42]. There are three main groups of floating foundations, based on how the design achieves its stability [43]:

- tension leg platforms (or simply TLPs), in which a light structure is semi-submerged and anchored to the seabed through tensioned mooring lines for stability;

- spar buoys, in which a very large cylindrical buoy stabilizes the wind turbine using ballast (the center of gravity is much lower than the center of buoyancy), e.g., Hywind; and

- $\quad$ semi-submersible, in which the main principles of the two previous designs are combined, i.e., a semi-submerged structure is added to reach the necessary stability (e.g., Wind-Float).

In this work, three commercial three-bladed horizontal axis turbines with different values of rated power $\left(P_{R}\right)$ and hub height were considered: the Senvion Repower 6.2 MW offshore (Siemens Gamesa, Zamudio, Spain), the Areva M5000 (Areva, Courbevoie, France) and the Siemens SWT-3.6-107 (Siemens Gamesa, Zamudio, Spain). Their power curves and technical specifications are shown in Figure 4 and Table 1, respectively [44] 


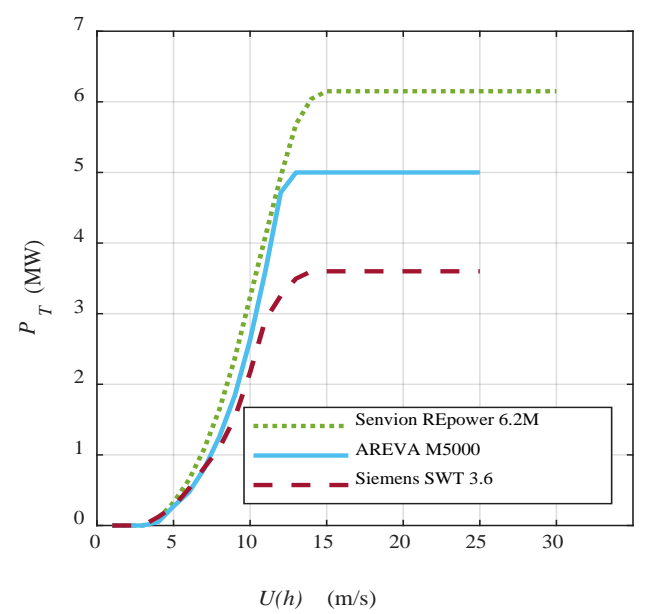

Figure 4. Power curves of the three wind turbines considered (data source: [44]).

Table 1. Technical specifications of the wind turbines considered (data source: [44]).

\begin{tabular}{ccccc}
\hline \multirow{2}{*}{ Parameter } & \multirow{2}{*}{ Units } & \multicolumn{3}{c}{ Wind Turbine } \\
\cline { 3 - 5 } & & Repower 6.2M & M5000 & SWT 3.6 \\
\hline$P_{R}$ & MW & 6.15 & 5.00 & 3.60 \\
Rotor diameter & $\mathrm{m}$ & 126.0 & 116.0 & 107.0 \\
Hub height & $\mathrm{m}$ & 95.0 & 90.0 & 88.0 \\
Cut-in wind speed & $\mathrm{m} / \mathrm{s}$ & 3.5 & 4.0 & 4.0 \\
Cut-off wind speed & $\mathrm{m} / \mathrm{s}$ & 30.0 & 25.0 & 25.0 \\
Manufacturer & - & Senvion & Areva & Siemens \\
\hline
\end{tabular}

\subsubsection{Offshore FPV Energy}

FPV systems can be deployed in the marine environment by means of structures with some similarity to those installed to date in lakes and reservoirs [45]. Most of these systems consist of photovoltaic panels that are kept afloat by connecting them to (rigid) pontoons (Figure 2) [46]. These designs would require some modifications for the marine environment-considering the structural loadings induced by wave action - which would increase their cost significantly. For this reason, flexible systems floating on the waterline have been proposed (Figure 2) [47]. The aim of the flexible designs is to reduce the load on the structure and its mooring, without compromising its survivability in harsh marine environments [18].

As regards the light absorbing materials, there are five main groups of photovoltaic technologies: crystalline silicon, cadmium telluride and cadmium sulphide, organic and polymer cells, hybrid photovoltaic cells and thin film technology [48]. Crystalline silicon is usually considered for rigid pontoon systems (it is only available in a rigid format), whereas thin film systems are proposed for the flexible systems [18].

Only crystalline silicon panels were considered in this work, as it remains the dominant technology in photovoltaic power modules up to date [48]. More specifically, three commercial photovoltaic (PV) panels were considered (Table 2). 
Table 2. Technical specifications of the solar photovoltaic (PV) panels considered (data source: [49-51]).

\begin{tabular}{ccccc}
\hline \multirow{2}{*}{ Parameter } & Units & \multicolumn{3}{c}{ Panel Model } \\
\cline { 3 - 5 } & & JKM 325PP-72V & Tallmax TSM-DE & Q-Power-G5 280 \\
\hline$P_{S T C}$ & $\mathrm{~W}$ & 325 & 365 & 280 \\
Efficiency & $\%$ & 16.75 & 18.8 & 17.1 \\
$\alpha_{P}$ & ${ }^{\circ} \mathrm{C}^{-1}$ & -0.4 & -0.39 & -0.40 \\
Length & $\mathrm{m}$ & 1.96 & 1.96 & 1.65 \\
Width & $\mathrm{m}$ & 0.99 & 0.99 & 0.99 \\
Surface & $\mathrm{m}^{2}$ & 1.94 & 1.95 & 1.94 \\
Weight & $\mathrm{kg}$ & 26.5 & 26.0 & 22.2 \\
Material & - & Si polycrystalline & Si monocrystalline & Si polycrystalline \\
Manufacturer & - & Jinko Solar & Trina Solar & Hanwa Q CELLS \\
\hline
\end{tabular}

\subsection{Parameter Estimation and Definition}

\subsubsection{Wind Energy Assessment}

It is well known that wind speed varies across the atmospheric boundary layer, and so does the energy resource. The wind speed profile across the boundary layer is mainly determined by the surface roughness characteristics, heat transfer and evaporation. Although complex wind profile expressions have been proposed, the most used wind speed profile-and the one used in this work-is the following [52]:

$$
U(z)=U_{r e f}\left(\frac{z}{z_{r e f}}\right)^{\alpha}
$$

where: $U$ is the mean wind speed at height $z$ above the sea surface; $U_{r e f}$ is the mean wind speed at the reference height $z_{\text {ref; }}$ and $\alpha$ is an empirical coefficient that accounts for the site- and time-specific atmospheric conditions. Based on previous work for a nearby coastal region in the Cantabrian Sea, a value of $\alpha=0.049$ was considered in this work [52]. Equation (1) was used to obtain the unknown value of $U_{T}$, the mean wind speed at the rotor height of a given wind turbine $(z)$, from the known values of $U_{10}$, the mean wind speed at a reference height of $z_{\text {ref }}=10 \mathrm{~m}$.

Prior to estimating the power output of the wind turbines, the time series of mean wind speeds were fitted to a Weibull distribution with the following probability density function [53]:

$$
f(U \mid a, b)=\left\{\begin{array}{cc}
0, & x<0 \\
\frac{b}{a}\left(\frac{U}{a}\right)^{b-1} e^{-(U / a)^{b}}, & x \geq 0
\end{array}\right.
$$

where $U$ is the wind speed, and $a$ and $b$ are the shape and scale parameters, respectively. Accordingly, the cumulative density function of Weibull distribution is given by

$$
F(U \mid a, b)=1-e^{-(U / a)^{b}} .
$$

Having determined the Weibull distribution at a specific location and height above sea level, the average wind power density can be obtained as [12]

$$
P_{W}=0.5 \rho_{a} \int U^{3} f(U) d U
$$

where $\rho_{a}$ is the air density.

The mean power output of a wind turbine at a specific location is obtained by combining the power curve of the turbine and the local wind speed distribution as follows [12]:

$$
\bar{P}_{W, \text { out }}=P_{T}\left(U_{T}\right) f\left(U_{T}\right),
$$


where $P_{T}\left(U_{T}\right)$ is the power curve defined as a density function of the mean wind speed at the hub height, and $f\left(U_{T}\right)$ is the Weibull probability density function of the mean wind speed at the rotor height. Accordingly, the energy output of a wind turbine in a given period of time $\left(E_{W, \text { out }}\right)$ can be easily obtained by multiplying the mean power output by the duration of the period. Another factor that can be used to assess the performance of a wind turbine is the capacity factor [12], which is the ratio of the mean power output within the period of time considered to the rated power of the turbine $\left(P_{R}\right)$,

$$
C F_{W}=\frac{\bar{P}_{W, o u t}}{P_{R}}
$$

As a reference, in 2017 the capacity factors of all the offshore wind farms in Europe ranged from $29 \%$ to $48 \%$ [54]. Nonetheless, it should be noted that the capacity factor varies greatly depending on the location, the total available resource and the power curve of the offshore wind turbine considered, and thus values across multiple regions should be compared with caution [55].

\subsubsection{Solar Energy Assessment}

The temperature-corrected power output of a given FPV panel is given by [56]:

$$
P_{S, o u t}=\eta P_{S T C}\left(\frac{R_{h o r}}{R_{S T C}}\right)\left[1-\alpha_{P}\left(T_{m}-T_{S T C}\right)\right],
$$

where: $\eta$ is a derating factor or performance ratio of the installation, which takes into account soiling of the panels, wiring losses, shading and aging, among other effects that reduce the efficiency of the system (absent shading, a representative value of $\eta=0.85$ was considered); $P_{\text {STC }}$ is the nominal power of the PV panel (i.e., its power output under Standard Test Conditions, STC); $R_{S T C}=1000 \mathrm{~W} / \mathrm{m}^{2}$ is the irradiance at STC; $\alpha_{P}$ is the temperature coefficient of power, which depends on the PV module; $T_{m}$ is the operational cell temperature; and $T_{S T C}=25^{\circ} \mathrm{C}$ is the reference cell temperature at STC. The value of $T_{m}$ for specific weather conditions and considering the water cooling of FPV panels can be obtained with the expression [17]:

$$
T_{m}=e_{0}+e_{1} T_{a}+e_{2} R_{h o r}-e_{3} U_{10}
$$

where $e_{0}=2.0458{ }^{\circ} \mathrm{C}, e_{1}=0.9458{ }^{\circ} \mathrm{C}^{-1}, e_{2}=0.0215^{\circ} \mathrm{C} \cdot \mathrm{m}^{2} \cdot$ day $\cdot \mathrm{kWh}^{-1}$ and $e_{3}=1.2376{ }^{\circ} \mathrm{C} \cdot \mathrm{s} \cdot \mathrm{m}^{-1}$ are empirical parameters obtained by adjusting observational data from a real installation. The energy output of an FPV panel $\left(E_{S, \text { out }}\right)$ can be simply obtained by integrating $P_{s, \text { out }}$ over time. As for the capacity factor of the FPV panel $\left(C F_{S}\right)$, it is defined as the ratio of its average power output over time to its nominal power,

$$
C F_{S}=\frac{\bar{P}_{S, \text { out }}}{P_{S T C}}
$$

which, depending of the latitude of the offshore FPV system, varies between $C F_{S}=8.6 \%$ at the Poles and $C F_{S}=20.5 \%$ at the Equator for crystalline PV panels [18].

\subsubsection{Specific Yield}

The marine surface area occupied by the project should be considered when comparing different marine renewable energy technologies. For this purpose, the specific yield is defined as the energy output per unit surface area in an average year [18]; for floating wind turbines, it is calculated as

$$
Y_{W}=E_{W, \text { out }} \frac{C D_{W}}{P_{R}}
$$

and for floating PV systems as

$$
Y_{S}=E_{S, \text { out }} \frac{C D_{S}}{P_{S T C}},
$$


where $C D_{W}$ and $C D_{S}$ are the capacity densities of wind and solar energy, respectively. The capacity density of a wind farm is defined as the ratio of the wind farm's rated capacity to its area, which includes the area occupied by the technology itself (footprint) and the area between the devices required to limit the wake effects or mooring/foundation interfaces. The optimal spacings between the offshore wind turbines usually vary between 5 and 15 rotor diameters along the prevailing wind direction, and between 5 and 12 rotor diameters along the crosswind direction [57].

Given the lack of real projects in the study area and bearing in mind the data from other European areas, a wind farm capacity density of $C D_{W}=5.36 \mathrm{MW} / \mathrm{km}^{2}$ was considered in this work [58]. As in the case of wind farms, the capacity density of FPV farms is defined based on their occupation area. According to Trapani et al. [18], typical values range between $C D_{S}=57$ and $74 \mathrm{MW} / \mathrm{km}^{2}$ when the panels are installed at a nearly horizontal angle. An average value of $C D_{S}=65 \mathrm{MW} / \mathrm{km}^{2}$ was chosen in this work.

\subsubsection{Power Output Variability and Power Smoothing (PS) Index}

The power output variability has been identified as a major cost driver in renewable energy projects. Moreover, a large variability can impede the penetration of offshore wind farms into the electricity market [58]. With the aim of achieving a smoother power output, diversified marine renewable energy farms have been proposed as a solution (e.g., combined wind-wave farms [59]).

The variability in the daily power output of a wind farm $\left(P_{w, \text { out }}\right)$ or an FPV farm $\left(P_{S, \text { out }}\right)$ is given by the coefficient of variation ( $C V_{W}$ or $C V_{S}$, respectively). To quantify the smoothing in the power output of offshore wind turbines due to their combination with FPV systems, a novel Power Smoothing (PS) index is proposed in this work,

$$
P S=\frac{C V_{W}-C V_{W S}}{C V_{W}}
$$

with $C V_{W S}$ the coefficient of variation of the daily power output of a combined offshore wind-solar farm.

\section{Results and Discussion}

\subsection{Offshore Wind Energy}

\subsubsection{Gross Resource}

Figure 5 depicts the variations in the wind power density across the study area. Given that each model of offshore wind turbine presents a different hub height, the values were computed with Equation (4) and the mean wind speeds at the reference height $\left(U_{10}\right)$. Values above $400 \mathrm{~kW} / \mathrm{m}^{2}$ (wind power class seven) are reached northwest of the study area, corresponding to locations with water depths above $200 \mathrm{~m}$. In most of the areas with water depths between 50 and $200 \mathrm{~m}$-where floating wind farms can be deployed - the wind power density ranges from 100 to $350 \mathrm{~kW} / \mathrm{m}^{2}$, corresponding to classes from two to six, in which wind energy development could be carried out [30]. 


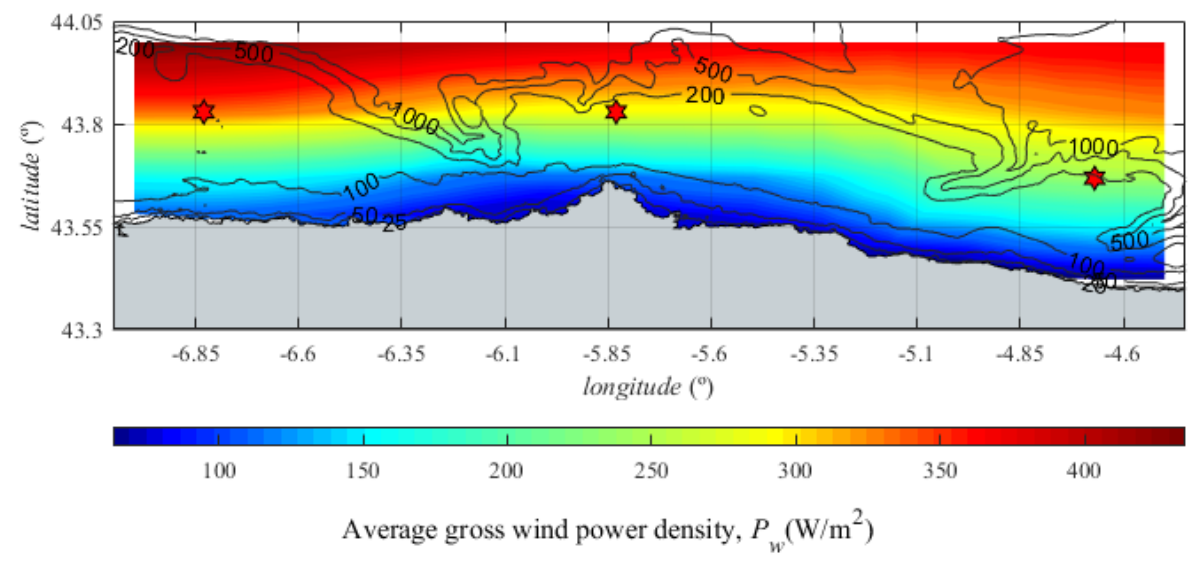

Figure 5. Average wind power density $\left(P_{w}\right)$ off Asturias. The three study sites (West, Centre and East) are marked with red stars. (Water depths in $\mathrm{m}$ ).

The results reveal three patterns in the spatial distribution of the resource (Figure 5). First, wind power density increases with distance from the coastline, from nearshore values below $100 \mathrm{~W} / \mathrm{m}^{2}$ to over $400 \mathrm{~W} / \mathrm{m}^{2}$ far offshore. Second, the resource decreases to the west and east of Cape Peñas, which may be explained by the sheltering effect of this headland. Third, the wind energy resource reduces slightly from West to East, which is apparent when comparing the wind speeds at the three study sites (Figure 6). The Weibull distributions peak at $U_{10}=4.30$ and $3.35 \mathrm{~m} / \mathrm{s}$ at the West and East sites, respectively.
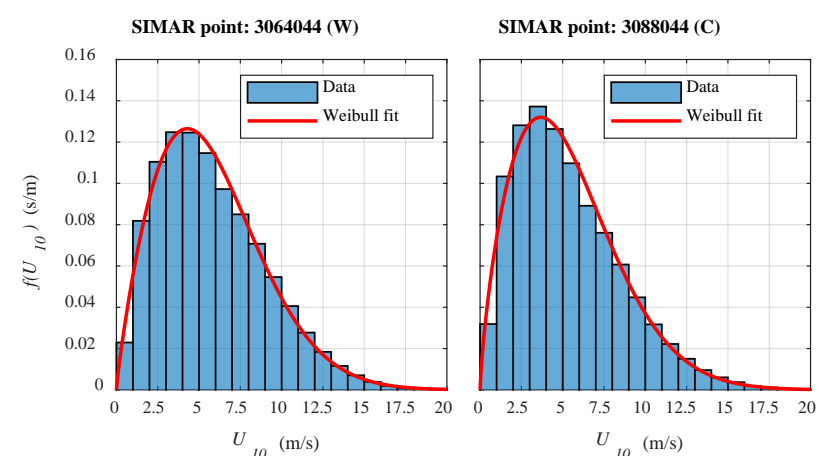

SIMAR point: 3116040 (E)
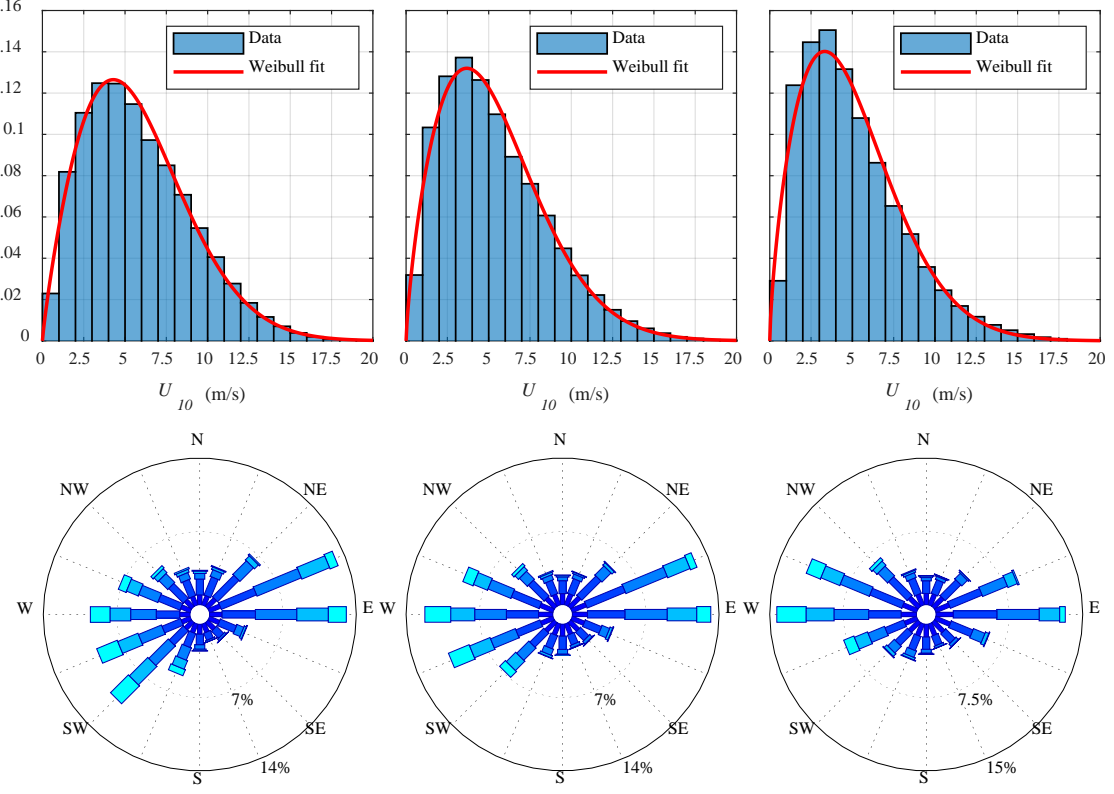

$U_{10}(\mathrm{~m} / \mathrm{s})$

$\mathrm{N}$

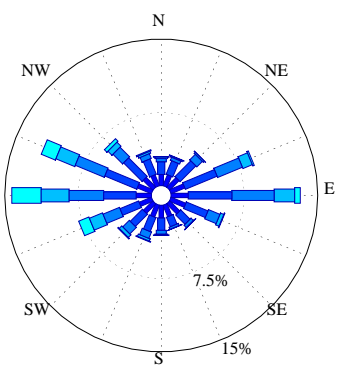

$U_{10}(\mathrm{~m} / \mathrm{s})$ $>10$ $7.5-10$
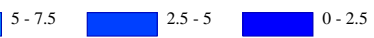

Figure 6. Probability Density Functions and wind roses at three study sites in the West, Centre, and East sections of the study area.

Regarding wind directions, both the dominant and prevailing wind directions present a westerly component-corresponding to the westerlies or anti-trades (Figure 6). As can be observed in the wind roses of the study sites, small differences occur due to the topographic effect of the continent nearby. 


\subsubsection{Performance Analysis}

The energy output of the three wind turbines considered differed significantly across the area of study (Figure 7). The greatest production corresponded to the Senvion Repower 6.2 MW turbine, with values above $15 \mathrm{GWh} /$ year for Northwestern locations. As expected, the spatial distribution of the energy output follows the pattern that was already described for the wind energy power density in Figure 5: the estimated energy output decreases towards the coast. Bearing in mind the high water depths off Asturias (Figure 3) and to maximize the energy output of the wind farms, floating foundations are required for the deployment of offshore wind turbines in the region.
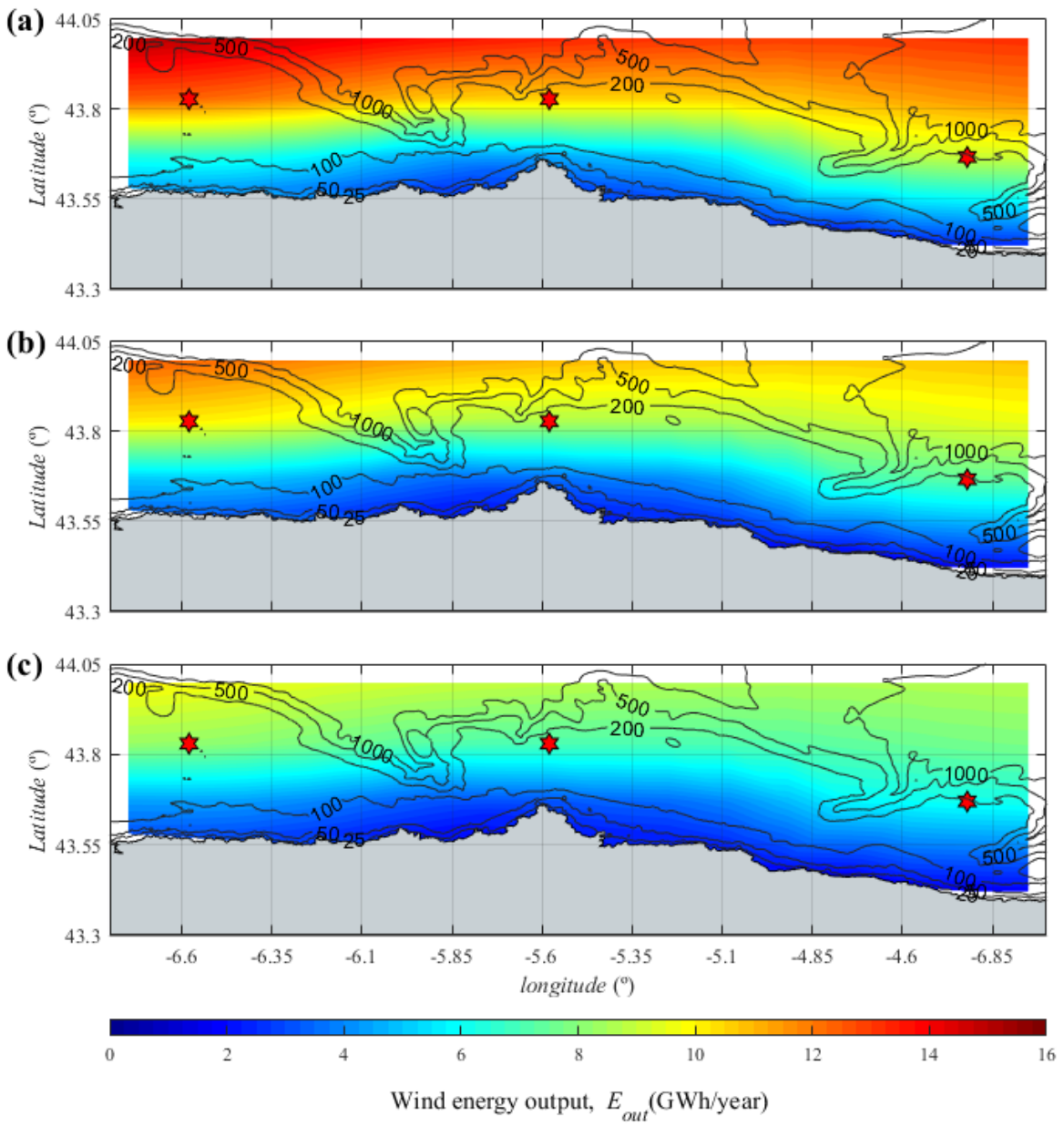

Figure 7. Expected wind energy output $\left(E_{w, \text { out }}\right)$ for three commercial wind turbines: Senvion REpower 6.2M (a), Areva M5000 (b) and Siemens SWT 3.6 (c). The three study sites (West, Centre and East) are marked with red stars. (Water depths in $\mathrm{m}$ ).

The capacity factor was calculated with Equation (6) for the three wind turbines at the three study sites (Table 2). It decreases with increasing rated power, and for a given turbine is maximum for the West study site. It is noticeable that, despite the high values obtained for the wind power density in the previous section, the capacity factor (between $C F_{W}=16 \%$ and $26 \%$ ) turns out to be small when compared with the typical values for offshore wind energy in Europe (commonly above $C F_{W}=29 \%$, [54]). The results in Table 3 are consistent with those reported for South West Portugal, where sites with similar levels of expected wind energy output $\left(E_{W, \text { out }} \sim 10 \mathrm{GWh} /\right.$ year) had capacity factors of $C F_{W}=25$ and 26\% for the Areva M5000 and the Senvion Repower 6.2M wind turbines, respectively [12]. 
Table 3. Capacity factor ( $C F$, with units of \%) of six commercial renewable energy technologies (three wind turbines and three PV panels) at the three study sites.

\begin{tabular}{cccc}
\hline & \multicolumn{3}{c}{ Study Site } \\
\cline { 2 - 4 } & W & C & E \\
\hline Senvion RE Power 6.2M & 23.1 & 19.2 & 16.2 \\
Areva M5000 & 23.0 & 19.7 & 16.8 \\
Siemens SWT 3.6 & 25.9 & 22.4 & 19.4 \\
\hline Q-Power-G5 280 & 12.8 & 12.6 & 13.2 \\
Tallmax TSM-DE & 11.7 & 11.5 & 12.1 \\
JKM 325PP-72V & 12.2 & 12.0 & 12.5 \\
\hline
\end{tabular}

\subsection{Offshore FPV Energy}

\subsubsection{Gross Resource}

The gross solar energy resource off the Asturian coast is mapped in Figure 8 based on the data obtained from the POWER datasets described in Section 2.2.2. POWER. The average solar irradiance varies across the study region, with values ranging from 125 to $165 \mathrm{~W} / \mathrm{m}^{2}$. The lowest values correspond to the vicinity of Cape Peñas and, especially, to eastern areas. The average irradiance increases from South to North within the study area (as expected for a region in the North Hemisphere) by about $10 \mathrm{~W} / \mathrm{m}^{2}$.

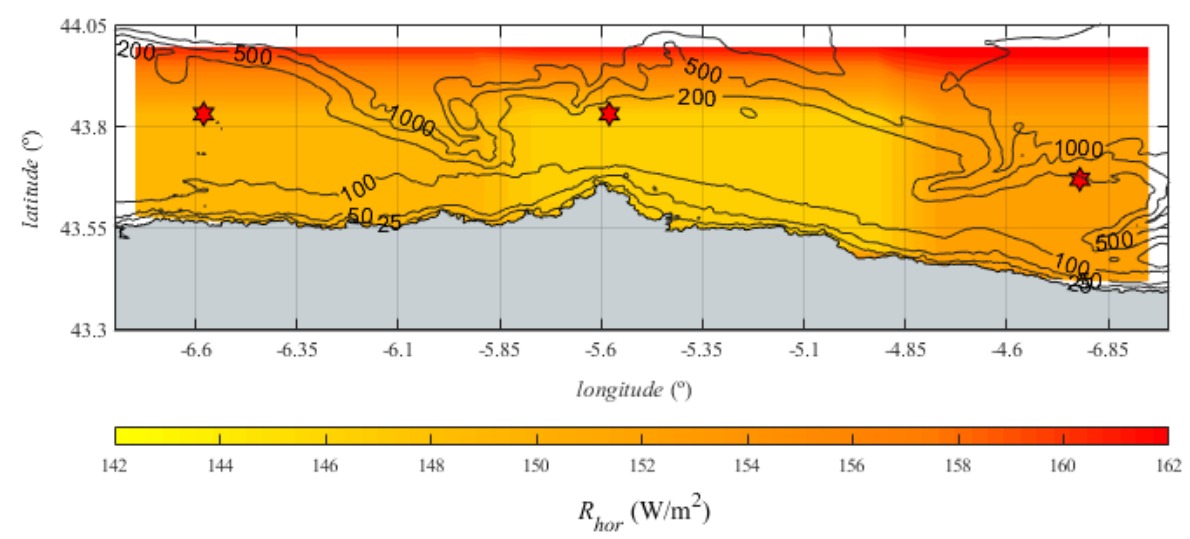

Figure 8. Average irradiance on a horizontal surface $\left(R_{h o r}\right)$ off Asturias. The three study sites (West, Centre and East) are marked with red stars. (Water depths in $\mathrm{m}$ ).

\subsubsection{Performance Analysis}

The power output of the three PV panels considered in Table 2 was estimated by means of Equation (7) for each time step and data point in the area of interest. Then, the energy output in an average year was estimated considering the panels with a horizontal layout (i.e., with $\eta=0.85$ ). The results are mapped in Figure 9.

Depending on the solar panel, the energy output varies between $\sim 300$ and $\sim 400 \mathrm{kWh}$ per average year across the region. The panel with the highest rated power and efficiency, the Tallmax TSM-DE (Trina Solar, Changzhou, China) produces the largest energy output in an average year (Table 1). As for the capacity factor, its values range between $12.2 \%$ and $13.2 \%$ with small differences between the three PV panels (Table 3).

The differences in the energy output are also small when comparing the results for a given PV panel at the three different study sites (W, C and E), showing that the influence of the water depth and/or the distance to the coast on the performance of the FPV systems across the study area is 
negligible. Therefore, there is no need in principle for deploying FPV farms in deep waters, apart from the availability of marine space or the synergies of joint deployment with, e.g., offshore wind turbines.
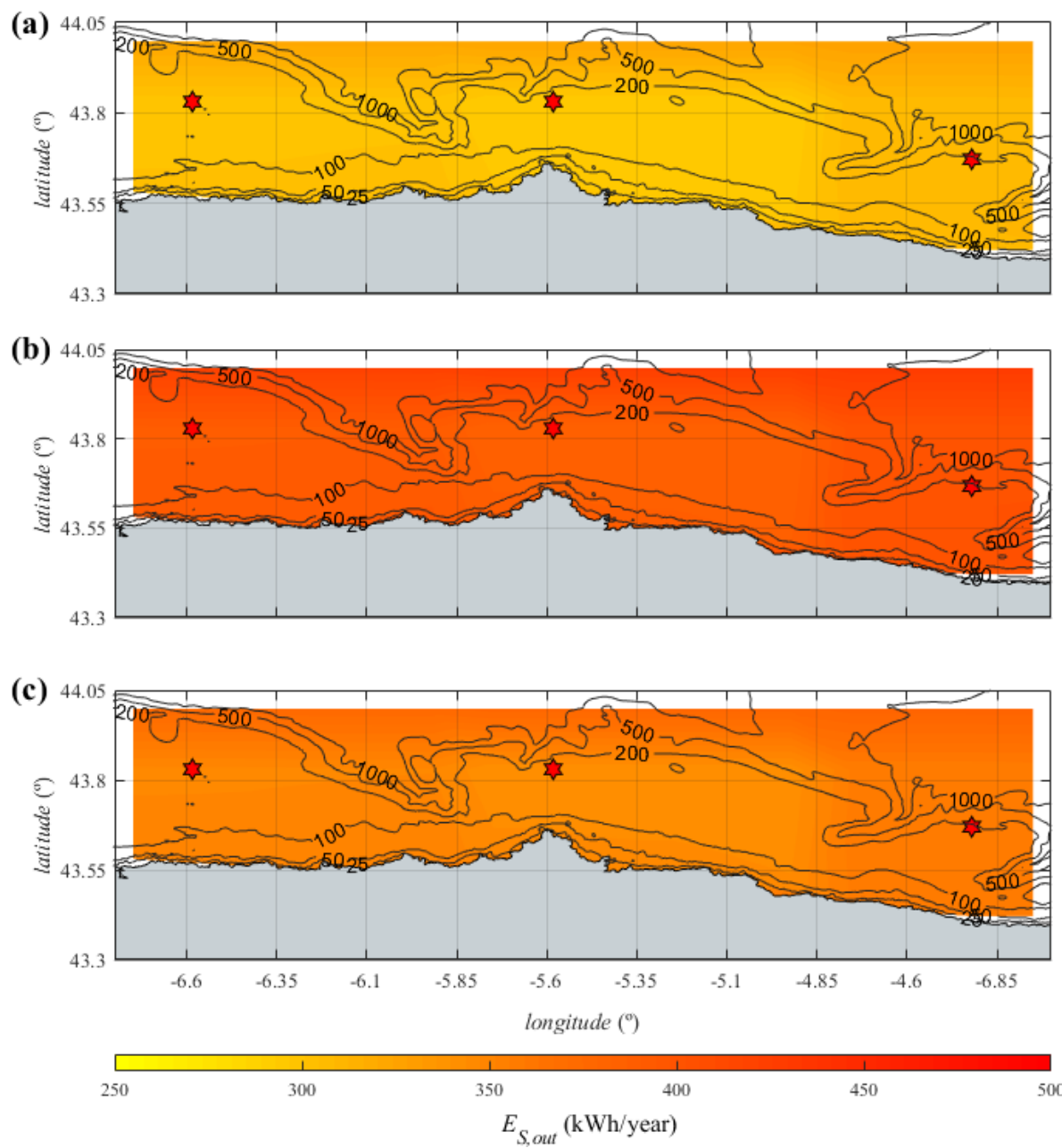

Figure 9. Expected solar energy output for three different commercial solar panels: Q-Power-G5 280 (a), Tallmax TSM-DE (b), and JKM 325PP-72V (c). The three study sites (West, Centre and East) are marked with red stars. (Water depths in $\mathrm{m}$ ).

\subsection{Comparative Analysis}

Given the difference in rated power between a single wind turbine and a single PV panel (6.2 MW vs. $365 \mathrm{~W}$, respectively), there is no point in comparing the energy production of single units. The apt comparison is between facilities with similar installed power. In this vein, the floating solar farm currently in operation at Fujian Zhangpu Zhuyu, China [19], with an installed power of 5 MW, was taken as a reference. The Senvion REPower 6.2M wind turbine and the Tallmax TSM-DE PV panel, which presented the best performance across the study area within their respective category, were selected as references for technical specifications (Figures 1 and 4).

The expected energy output of the solar farm at the three study sites is about half the expected energy output of the wind turbine (Table 4). As for the capacity factor, the values of the wind turbine are nearly twice as large as those of the FPV farm. This result would point in principle to a better performance of the wind turbines in comparison to FPV systems, but the variability of the power output and the area of the project should also be considered. 
Table 4. Energy production $(E)$, coefficient of variation $(C V)$, specific yield $(Y)$ and capacity factor $(C F)$ for the offshore wind turbine and the offshore FPV farm.

\begin{tabular}{cccccc}
\hline & Parameter & Units & \multicolumn{3}{c}{ Study Site } \\
\cline { 3 - 6 } & & & W & C & E \\
\hline \multirow{3}{*}{ 6.2 MW offshore wind turbine } & $E_{W, \text { out }}$ & $\mathrm{GWh} /$ year & 12.4 & 10.6 & 9.0 \\
& $C V_{W}$ & - & 1.3 & 1.4 & 1.6 \\
& $Y_{W, \text { out }}$ & $\mathrm{GWh} /\left(\mathrm{km}^{2} \cdot\right.$ year $)$ & 10.6 & 9.2 & 7.8 \\
& $C F_{W}$ & $\%$ & 23.1 & 19.2 & 16.2 \\
\hline \multirow{3}{*}{5 MW offshore FPV farm } & $E_{S, \text { out }}$ & $\mathrm{GWh} /$ year & 5.3 & 5.2 & 5.5 \\
& $C V_{S}$ & - & 0.6 & 0.6 & 0.6 \\
& $Y_{S, \text { out }}$ & $\mathrm{GWh} /\left(\mathrm{km}^{2} \cdot\right.$ year $)$ & 69.4 & 67.6 & 71.5 \\
& $C F_{S}$ & $\%$ & 11.7 & 11.5 & 12.1 \\
\hline
\end{tabular}

The power output for the FPV farm presents a coefficient of variation $C V_{S} \approx 0.60$ for the three reference sites, which is half the wind turbine counterpart (Table 4). Based on the climate of the region, patterns can be recognized. The energy output of the wind turbine in winter doubles the summer values. The opposite holds for the FPV farm, with energy outputs in summer months up to three times higher. In fact, the energy output of the FPV farm increases to such an extent during summer that for the study site $\mathrm{E}$ it surpasses the energy production of the wind turbine (Figure 10).

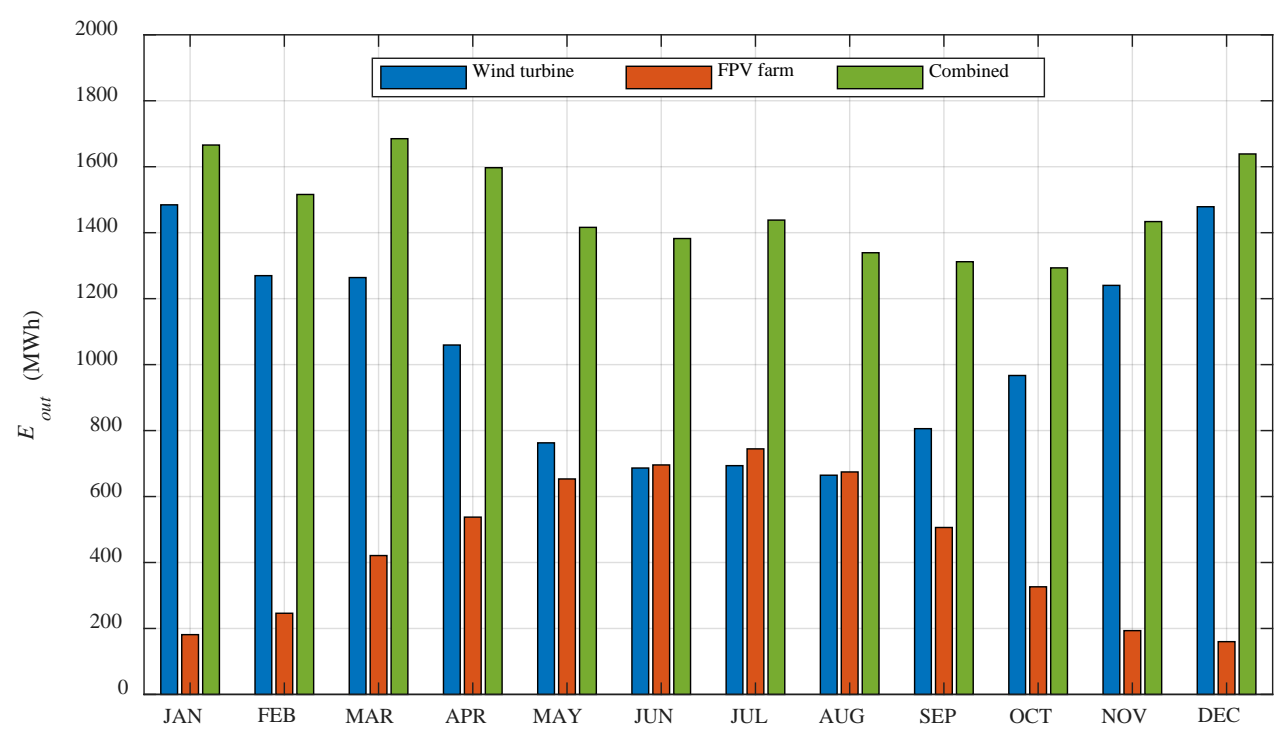

Figure 10. Monthly energy production at study site East of a 6.2 MW offshore wind turbine, a $5 \mathrm{MW}$ FPV farm, and both combined.

The specific yield of each technology was obtained with Equations (10) and (11) for the three study sites. The results are summarized in Table 3. The values obtained for the offshore wind turbine across the study area vary between 7.8 and $10.6 \mathrm{GWh} / \mathrm{km}^{2}$ per average year, whereas the values for the FPV farm vary little around $\sim 70 \mathrm{GWh} / \mathrm{km}^{2}$. Therefore, FPV systems would be nearly seven times more productive than offshore wind turbines for the same project area. This result is in part due to the fact that the area occupied by a wind farm includes "empty" spacing between turbines, whereas the area occupied by a solar project is all but entirely covered by the FPV systems.

\subsection{Combined Offshore Wind and FPV Farm}

Combining offshore wind turbines and FPV systems presents a series of advantages relative to conventional offshore wind farms. First and foremost, conventional offshore wind farms require large 
empty marine surface areas in between the turbines. In a combined farm, these surface areas are occupied with FPV systems which increases the capacity density. Consider a typical wind farm capacity density $\left(C D_{W}=5.36 \mathrm{MW} / \mathrm{km}^{2}\right)$ and the layout in Figure 2. The maximum surface area available for deploying FPV systems between wind turbines of the model Senvion Repower 6.2 MW (with a rotor diameter of $126 \mathrm{~m}$ ) would vary between $64 \%$ and $86 \%$ of the total area, depending on the relationship between the turbine spacing in the prevailing wind direction and the turbine spacing in the crosswind direction (Figure 2). Accordingly, the share of FPV power in the combined offshore wind-solar farm would vary between $73 \%$ and $96 \%$ of the installed capacity. The capacity density of the combined farm would be $\sim 57.5 \mathrm{MW} / \mathrm{km}^{2}$ in all cases, which is ten times higher than the value of a conventional wind farm.

Regarding the capacity factor, a combined farm at study site E, for example, would present a value between $12.1 \%$ (pure offshore FPV farm) and 16.2\% (pure offshore wind farm), depending on the share of FPV power in the total installed capacity (Figure 11). In terms of the specific yield, if the maximum typical spacing between the wind turbines is considered, a combined farm would produce a specific yield of up to $61.2 \mathrm{GWh} /\left(\mathrm{km}^{2}\right.$.year $)$ at study site E-more than seven times the specific yield of wind turbines (Table 4). It follows that a combined offshore wind-solar farm can produce significantly more energy per surface unit area than an offshore wind farm.

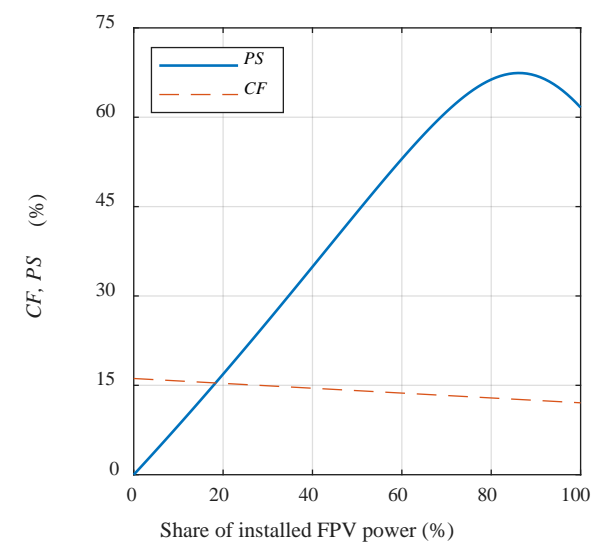

Figure 11. Capacity factor, $C F$, and Power Smoothing index, $P S$, for combined offshore wind and FPV farms as a function of share of installed FPV power capacity.

Another advantage is that the combination of FPV systems with offshore wind turbines significantly reduces the intra-annual variability of the energy output, which is one of the downsides of marine renewable energy [60]. This reduction is apparent in Figure 10. In the same line, hybrid systems present lower values of the coefficient of variability of power output. This is made apparent by the Power Smoothing (PS) index, which is plotted in Figure 11 as a function of the share of FPV installed power with respect to the total installed power of the hybrid farm at study site E. The PS index peaks at $68 \%$ for an FPV installed power share of $86 \%$, implying a very substantial reduction in the variability of the power output with respect to the wind turbine. Moreover, the power output variability of the combined wind-solar farm $\left(C V_{\text {WS }}=0.51\right)$ is also significantly lower $(\sim 20 \%)$ than that of a stand-alone FPV farm (Table 4). It follows that hybrid systems combining FPV with offshore wind produce a smoother power output than conventional systems with either stand-alone wind or FPV—a significant advantage.

The latter results have been obtained without considering the issue of shading. Intermittent shadows from the rotors and towers of the wind turbines may affect the performance of the FPV systems.

\section{Conclusions}

The first research into combining offshore wind and solar power was conducted in this work through a case study off Asturias (North Spain). Floating technology would be required virtually 
anywhere in the study area, given that water depths exceed $50 \mathrm{~m}$ except in a narrow coastal fringe. The performance of several technologies-three wind turbines and three solar panels, separately and in combination-was examined by considering the energy output, the specific yield, the power output variability, and the capacity factor. Bearing in mind the results, a combined offshore wind-solar farm is proposed and its performance examined.

The wind energy resource across the study area decreases towards the coast, from $\sim 400 \mathrm{~W} / \mathrm{m}^{2}$ in the deeper parts to $\sim 100 \mathrm{~W} / \mathrm{m}^{2}$ near shore. The wind turbine with the highest rated power would yield $15 \mathrm{GWh} /$ year in the North West section of the study area, which corresponds approximately to the limit of the continental shelf-where water depths increase abruptly from $200 \mathrm{~m}$ to over $1000 \mathrm{~m}$.

As for the solar resource, the horizontal irradiance on a horizontal surface varies only weakly across the study area, with values of approx. $150 \mathrm{~W} / \mathrm{m}^{2}$, while the expected energy output for a commercial PV panel would vary between 300 to $400 \mathrm{kWh} /$ year, depending on the model and the location. Unlike wind energy, the expected solar energy output varies little across the study area. Therefore, power plants in deep waters would not be required to maximize the solar energy output-an advantage of offshore PV farms versus offshore wind energy farms.

When the performance of a commercial 6.2 MW wind turbine and a $5 \mathrm{MW}$ FPV farm are compared, the former presents far higher values of the energy output and the capacity factor. This first approximation could be considered favourable to wind energy, but the FPV farm presents a much lower variability of the production, and its specific yield is some seven times higher. These properties justify combining both with a view to smoothing the power output and realising economies of scale.

On this basis, a hybrid system was proposed and the production synergies were investigated. A combined offshore wind-solar farm can reach $57.5 \mathrm{MW} / \mathrm{km}^{2}$ of capacity density and $61.2 \mathrm{GWh} /\left(\mathrm{km}^{2}\right.$.year $)$ of specific yield-10 and 7 times the typical values for stand-alone offshore wind turbines, respectively. Furthermore, the power output of offshore wind turbines and FPV systems is significantly smoothed when both are combined, with a $68 \%$ reduction in the power output variability relative to a stand-alone wind farm.

In summary, a hybrid marine renewable energy farm with offshore wind turbines and FPV would not only increase the power output per unit surface area of marine space, but also improve the quality of the power output by reducing its temporal variability.

Author Contributions: Conceptualization, M.L., N.R. and G.I.; methodology, M.L., N.R. and G.I.; software, M.L. and N.R.; resources, N.R.; writing — original draft preparation, M.L.; writing-review and editing, G.I.; funding acquisition, M.L. and G.I. All authors have read and agreed to the published version of the manuscript.

Funding: This research was partially funded by the Ports Towards Energy Self-Sufficiency (PORTOS) project co-financed by the Interreg Atlantic Area Programme through the European Regional Development Fund, grant number EAPA_784/2018, and by the Council of Gijón through the University Institute of Industrial Technology of Asturias, grant number SV-20-GIJON-1-19 (the views and opinions expressed herein do not necessarily reflect those of the University Institute of Industrial Technology of Asturias-IUTA).

Acknowledgments: Wind datasets were provided by the Spanish government agency Puertos del Estado (Ministerio de Fomento). Irradiance datasets were obtained from the NASA Langley Research Center Atmospheric Science Data Center Surface meteorological and Solar Energy (SSE) web portal supported by the NASA LaRC POWER Project.

Conflicts of Interest: The authors declare no conflict of interest. The funders had no role in the design of the study; in the collection, analyses, or interpretation of data; in the writing of the manuscript, or in the decision to publish the results.

\section{References}

1. Pedersen, P.T. Marine Structures: Future Trends and the Role of Universities. Engineering 2015, 1, 131-138. [CrossRef]

2. Taveira-Pinto, F.F.; Iglesias, G.; Rosa-Santos, P.; Deng, Z.D. Preface to Special Topic: Marine Renewable Energy. J. Renew. Sustain. Energy 2015, 7, 5. [CrossRef]

3. Iglesias, G.; López, M.; Carballo, R.; Castro, A.; Fraguela, J.A.; Frigaard, P. Wave energy potential in Galicia (NW Spain). Renew. Energy 2009, 34, 2323-2333. [CrossRef] 
4. López, M.; Taveira-Pinto, F.; Rosa-Santos, P. Numerical modelling of the CECO wave energy converter. Renew. Energy 2017, 113, 202-210. [CrossRef]

5. Fernandez, H.; Iglesias, G.; Carballo, R.; Castro, A.; Fraguela, J.A.; Taveira-Pinto, F.; Sanchez, M. The new wave energy converter WaveCat: Concept and laboratory tests. Mar. Struct. 2012, 29, 58-70. [CrossRef]

6. Veigas, M.; López, M.; Romillo, P.; Carballo, R.; Castro, A.; Iglesias, G. A proposed wave farm on the Galician coast. Energy Convers. Manag. 2015, 99, 102-111. [CrossRef]

7. Antonio, F.D.O. Wave energy utilization: A review of the technologies. Renew. Sustain. Energy Rev. 2010, 14, 899-918. [CrossRef]

8. Pacheco, A.; Ferreira, Ó.; Carballo, R.; Iglesias, G. Evaluation of the production of tidal stream energy in an inlet channel by coupling field data and numerical modelling. Energy 2014, 71, 104-117. [CrossRef]

9. Alvarez, E.A.; Rico-Secades, M.; Suárez, D.F.; Gutiérrez-Trashorras, A.J.; Fernández-Francos, J. Obtaining energy from tidal microturbines: A practical example in the Nalón River. Appl. Energy 2016, 183, 100-112. [CrossRef]

10. Esteban, M.D.; Diez, J.J.; López, J.S.; Negro, V. Why offshore wind energy? Renew. Energy 2011, 36. [CrossRef]

11. Esteban, M.D.; López-Gutiérrez, J.S.; Negro, V.; Matutano, C.; García-Flores, F.M.; Millán, M.Á. Offshore wind foundation design: Some key issues. J. Environ. Eng. 2015, 141, 1-6. [CrossRef]

12. Pacheco, A.; Gorbeña, E.; Sequeira, C.; Jerez, S. An evaluation of offshore wind power production by floatable systems: A case study from SW Portugal. Energy 2017, 131, 239-250. [CrossRef]

13. Kim, H.C.; Kim, M.H.; Lee, J.Y.; Kim, E.S.; Zhang, Z. Global Performance Analysis of 5MW WindFloat and OC4 Semi-Submersible Floating Offshore Wind Turbines (FOWT) by Numerical Simulations. In Proceedings of the 27th International Ocean and Polar Engineering Conference, San Francisco, CA, USA, 25-30 June 2017.

14. Kumar, V.; Shrivastava, R.L.; Untawale, S.P. Solar Energy: Review of Potential Green \& Clean Energy for Coastal and Offshore Applications. Aquat. Procedia 2015, 4, 473-480. [CrossRef]

15. Santafé, M.R.; Ferrer Gisbert, P.S.; Sánchez Romero, F.J.; Torregrosa Soler, J.B.; Ferrán Gozálvez, J.J.; Ferrer Gisbert, C.M. Implementation of a photovoltaic floating cover for irrigation reservoirs. J. Clean. Prod. 2014, 66, 568-570. [CrossRef]

16. Skoplaki, E.; Palyvos, J.A. On the temperature dependence of photovoltaic module electrical performance: A review of efficiency/power correlations. Sol. Energy 2009, 83, 614-624. [CrossRef]

17. Kamuyu, W.C.L.; Lim, J.R.; Won, C.S.; Ahn, H.K. Prediction model of photovoltaic module temperature for power performance of floating PVs. Energies 2018, 11, 447. [CrossRef]

18. Trapani, K.; Millar, D.L.; Smith, H.C.M. Novel offshore application of photovoltaics in comparison to conventional marine renewable energy technologies. Renew. Energy 2013, 50, 879-888. [CrossRef]

19. Wu, Y.; Li, L.; Song, Z.; Lin, X. Risk assessment on offshore photovoltaic power generation projects in China based on a fuzzy analysis framework. J. Clean. Prod. 2019, 215, 46-62. [CrossRef]

20. Solanki, C.; Nagababu, G.; Kachhwaha, S.S. Assessment of offshore solar energy along the coast of India. Energy Procedia 2017, 138, 530-535. [CrossRef]

21. Trapani, K.; Millar, D.L. Proposing offshore photovoltaic (PV) technology to the energy mix of the Maltese islands. Energy Convers. Manag. 2013, 67, 18-26. [CrossRef]

22. Friel, D.; Karimirad, M.; Whittaker, T.; Doran, W.J.; Howlin, E. A review of floating photovoltaic design concepts and installed variations. In Proceedings of the 4th International Conference Offshore Renew Energy CORE 2019, Glasgow, UK, 30 August 2019; pp. 1-10.

23. Pérez-Collazo, C.; Greaves, D.; Iglesias, G.; Perez-Collazo, C.; Greaves, D.; Iglesias, G. A review of combined wave and offshore wind energy. Renew. Sustain. Energy Rev. 2015, 42, 141-153. [CrossRef]

24. Astariz, S.; Perez-Collazo, C.; Abanades, J.; Iglesias, G. Towards the optimal design of a co-located wind-wave farm. Energy 2015, 84, 15-24. [CrossRef]

25. Astariz, S.; Perez-Collazo, C.; Abanades, J.; Iglesias, G. Co-located wind-wave farm synergies (Operation \& Maintenance): A case study. Energy Convers. Manag. 2015, 91, 63-75. [CrossRef]

26. Zheng, X.; Zheng, H.; Lei, Y.; Li, Y.; Li, W. An offshore floating wind-solar-aquaculture system: Concept design and extreme response in survival conditions. Energies 2020, 13, 604. [CrossRef]

27. Iglesias, G.; Carballo, R. Offshore and inshore wave energy assessment: Asturias (N Spain). Energy 2010, 35, 1964-1972. [CrossRef]

28. Abanades, J.; Flor-Blanco, G.; Flor, G.; Iglesias, G. Dual wave farms for energy production and coastal protection. Ocean. Coast. Manag. 2018, 160, 18-29. [CrossRef] 
29. Ramos, V.; Carballo, R.; Álvarez, M.; Sánchez, M.; Iglesias, G. Assessment of the impacts of tidal stream energy through high-resolution numerical modeling. Energy 2013, 61, 541-554. [CrossRef]

30. Elliott, D.L.; Holladay, C.G.; Barchet, W.R.; Foote, H.P.; Sandusky, W.F. Wind energy resource atlas of the United States. STIN 1987, 87, 24819.

31. Zheng, C.W.; Pan, J. Assessment of the global ocean wind energy resource. Renew. Sustain. Energy Rev. 2014, 33, 382-391. [CrossRef]

32. Prieto, J.I.; Martínez García, J.C.; García, D.; Santoro, R. Notes on the solar map of Asturias. Renew. Energy Power Qual. J. 2011, 1273-1277. [CrossRef]

33. Vázquez, M.V.; Varela, M.P.; Belmonte, P.I.; Cerqueira, M.T.P. Zonas climáticas de radiación solar de Galicia. In Proceedings of the Construyendo el Futuro Sostenible: Libro de Actas del XIV Congreso Ibérico y IX Congreso Iberoamericano de Energía Solar, Vigo, Galicia, España, 17-21 June 2008; pp. 255-260.

34. Samuelsson, P.; Jones, C.G.; Will' En, U.; Ullerstig, A.; Gollvik, S.; Hansson, U.L.; Jansson, E.; Kjellstro, M.C.; Nikulin, G.; Wyser, K. The Rossby Centre Regional Climate model RCA3: Model description and performance. Tellus A Dyn. Meteorol. Oceanogr. 2011, 63, 4-23. [CrossRef]

35. Uppala, S.M.; Kållberg, P.W.; Simmons, A.J.; Andrae, U.; Bechtold, V.D.C.; Fiorino, M.; Gibson, J.K.; Haseler, J.; Hernandez, A.; Kelly, G.A.; et al. The ERA-40 re-analysis. Q. J. R. Meteorol. Soc. 2005, 131, 2961-3012. [CrossRef]

36. Cats, G.; Wolters, L. The Hirlam project. IEEE Comput. Sci. Eng. 1996, 3, 4-7. [CrossRef]

37. Iglesias, G.; Carballo, R. Wave energy and nearshore hot spots: The case of the SE Bay of Biscay. Renew. Energy 2010, 35, 2490-2500. [CrossRef]

38. Stackhouse, P.W.; Zhang, T.; Westberg, D.; Barnett, A.J.; Bristow, T.; Macpherson, B.; Hoell, J.M. POWER Release 8 (with GIS Applications) Methodology (Data Parameters, Sources, E Validation) Documentation Date (All Previous Versions Are Obsolete) (Data Version 8.0.1); NASA: Washington, DC, USA, 2018.

39. Zhang, T.; Stackhouse, P.W.; Chandler, W.S.; Hoell, J.M.; Westberg, D.; Whitlock, C.H. A global perspective on renewable energy resources: NASA's Prediction of Worldwide Energy Resources (POWER) Project. In Proceedings of the 2007 ISES Solar World Congress, Beijing, China, 18-21 September 2007; Volume 4, pp. 2636-2640.

40. Gelaro, R.; Mccarty, W.; Suárez, M.J.; Todling, R.; Molod, A.; Takacs, L.; Randles, C.; Darmenov, A.; Bosilovich, M.G.; Reichle, R.H.; et al. The modern-era retrospective analysis for research and applications, version 2 (MERRA-2). J. Clim. 2017, 30, 5419-5454. [CrossRef]

41. Rienecker, M.M.; Suarez, M.J.; Todling, R.; Bacmeister, J.; Takacs, L.; Liu, H.C.; Gu, W.; Sienkiewicz, M.; Koster, R.D.; Gelaro, R.; et al. The GEOS-5 Data Assimilation System: Documentation of Versions 5.0.1, 5.1.0, and 5.2.0; NASA Goddard Space Flight Center: Greenbelt, MD, USA, 2008.

42. Oh, K.Y.; Nam, W.; Ryu, M.S.; Kim, J.Y.; Epureanu, B.I. A review of foundations of offshore wind energy convertors: Current status and future perspectives. Renew. Sustain. Energy Rev. 2018, 88, 16-36. [CrossRef]

43. EWEA European Wind Energy Association: Deep water-The next step for offshore wind energy. 2013.

44. Carrillo, C.; Obando Montaño, A.F.; Cidrás, J.; Díaz-Dorado, E. Review of power curve modelling for windturbines. Renew. Sustain. Energy Rev. 2013, 21, 572-581. [CrossRef]

45. Ranjbaran, P.; Yousefi, H.; Gharehpetian, G.B.; Astaraei, F.R. A review on floating photovoltaic (FPV) power generation units. Renew. Sustain. Energy Rev. 2019, 110, 332-347. [CrossRef]

46. Patil, S.S.; Wagh, M.M.; Shinde, N.N. A Review on Floating Solar Photovoltaic Power Plants. Int. J. Sci. Eng. Res. 2017, 8, 789-794.

47. Trapani, K.; Millar, D.L. The thin film flexible floating PV (T3F-PV) array: The concept and development of the prototype. Renew. Energy 2014, 71, 43-50. [CrossRef]

48. Parida, B.; Iniyan, S.S.; Goic, R. A review of solar photovoltaic technologies. Renew. Sustain. Energy Rev. 2011, 15, 1625-1636. [CrossRef]

49. Jinkosolar. Eagle 72P-V 320-340 Watt. 2017. Available online: https://jinkosolar.eu (accessed on 15 June 2019).

50. Trinasolar. Tallmax Plus TSM-DE14A (II). 2017. Available online: https://www.trinasolar.com (accessed on 15 June 2019).

51. Q-CELLS. Q.POWER-G5 260-280. 2017. Available online: https://www.q-cells.com (accessed on 15 June 2019).

52. Del Jesus, F.; Menéndez, M.; Guanche, R.; Losada, I.J. A wind chart to characterize potential offshore wind energy sites. Comput. Geosci. 2014, 71, 62-72. [CrossRef] 
53. Ramos, V.; Iglesias, G. Wind power viability on a small island. Int. J. Green Energy 2014, 11, 741-760. [CrossRef]

54. Wind Europe. Offshore Wind in Europe. Key Trends and Statistics 2017; Wind Europe: Brussels, Belgium, 2018.

55. Weaver, T. Financial appraisal of operational offshore wind energy projects. Renew. Sustain. Energy Rev. 2012, 16, 5110-5120. [CrossRef]

56. Sukarso, A.P.; Kim, K.N. Cooling effect on the floating solar PV: Performance and economic analysis on the case of west Java province in Indonesia. Energies 2020, 13, 2126. [CrossRef]

57. Gao, X.; Yang, H.; Lu, L. Investigation into the optimal wind turbine layout patterns for a Hong Kong offshore wind farm. Energy 2014, 73, 430-442. [CrossRef]

58. Hundleby, G.; Freeman, K. Unleashing Europe's Offshore Wind Potential: A New Resource Assessment; BVG Associates: Swindon, UK, 2017.

59. Astariz, S.; Iglesias, G. Output power smoothing and reduced downtime period by combined wind and wave energy farms. Energy 2016, 97, 69-81. [CrossRef]

60. Carballo, R.; Sanchez, M.; Ramos, V.; Fraguela, J.A.; Iglesias, G. The intra-annual variability in the performance of wave energy converters: A comparative study in N Galicia (Spain). Energy 2015, 82, 138-146. [CrossRef]

(C) 2020 by the authors. Licensee MDPI, Basel, Switzerland. This article is an open access article distributed under the terms and conditions of the Creative Commons Attribution (CC BY) license (http://creativecommons.org/licenses/by/4.0/). 